\title{
Financial Management Practices by Small and Micro Enterprise Owners in Ghana - Evidence from the Central Region
}

\author{
John Kwaning Mbroh ${ }^{1}$, Seth Quartey ${ }^{2}$ \\ ${ }^{1}$ Dept. of Accountancy Studies, School of Business \&Mgt. Studies, Cape Coast Polytechnic, Cape Coast, Ghana \\ ${ }^{2}$ KNUST CEMBA Program, IDL, KNUST, Kumasi, Ghana \\ Email address: \\ johnkmbroh@gmail (J. K. Mbroh), john.mbroh@cpoly.edu.gh (J. K. Mbroh), sethquartey42@yahoo.co.uk (S. Quartey)
}

\section{To cite this article:}

John Kwaning Mbroh, Seth Quartey. Financial Management Practices by Small and Micro Enterprise Owners in Ghana - Evidence from the Central Region. International Journal of Economics, Finance and Management Sciences. Vol. 3, No. 5, 2015, pp. $494-506$.

doi: 10.11648/j.ijefm.20150305.21

\begin{abstract}
In Ghana, small and micro enterprise owners (SMEOs) face a lot of business management challenges and it is alleged that they suffer, mostly, in terms of their financial management practices. Using a purposive sampling technique in a self-administered data collection, this study attempts to highlight the specific financial management practices by the selected business owners. In all, 372 SMEOs responded and this was made up of the small enterprise segment (118) and the micro enterprises (254), selected from the twenty administrative district capitals in the Central Region of Ghana. The findings show how haphazard, perhaps carelessly, the business owners have financially managed their respective enterprises. Indeed, only $13 \%$ of the respondents actually understand the meaning of financial management, and regardless of the business segment differences, majority (36\%) of the respondents had misconceived that maintaining proper financial records was all that financial management meant. Further worrying, is the fact that only $13 \%$ of overall respondents were specific that they did not understand the meaning of financial management, in addition to several intriguing revelations. The study recommends stakeholder collaborative efforts involving business schools in both polytechnics and universities with relevant agencies and NGOs in building the financial management skills and capacities of the business owners. On their own, the enterprise owners have been advised to urgently take steps to acquire these relevant skills since they need and benefit most. Future research recommendations include a study on the impact of financial management on these businesses.
\end{abstract}

Keywords: Small and Micro Enterprise Owners (SMEOs), Financial Management, Small Businesses, Micro Businesses

\section{Introduction}

Every business is formed and run with financial and other resources even though eventually, the level of financial resources available will determine the timing, size and deployment of the other resources. Indeed, the available 'scarce' finance must be religiously managed to achieve the general management results in the respective business. In other words, it is only through the efficient management of finance that the objectives of a business may be achieved. Precisely, finance has an integral influence on the general resource allocation in every business. As such, underlying the basis for resource allocation is the concept of financial management. However, financial management in itself is a skill or knowhow which must be acquired on its terms. Every business must get its tenets right in order to succeed. In the words of
McMenamin (1999), financial management may simply be defined as 'the ways and means of managing money'. More formally, it is the determination, acquisition, allocation, and utilization of financial resources, usually with the aim of achieving some particular goals or objectives. Small and micro businesses (SMEs) in Ghana continue to receive stakeholder attention in all respects due to their crucial roles in engineering the economic development and growth as well as the employment agenda of the country. Crucial to this noble course is the extent of financial management capabilities and practices. Currently in Ghana, they already face a lot of funding challenges with the commercial banks. For instance, Mbroh and Koomson (2015) concluded that the main challenge faced by these businesses with the banks' existing credit policy (system), was the bureaucratic processes within the banks that create undue delays in loan acquisitions. 
However, according to Quartey and Kayanula (2000) the small and medium enterprises account for $15.5 \%$ of the labour force as well as $6 \%$ of the GDP in 1998. In support, the AGI (2006) observed that the dynamic role of small and medium scale enterprises in developing countries as engines through which the growth objectives can be achieved cannot be underestimated. In his view, Kuffour (2008) noted that the role of small and medium scale enterprises in facilitating global economic development has attracted increasing attention over the past decade. The small business sector is seen as an important contributor in the transition to a market economy, through the processes of innovation, job creation, income generation and business dynamics. However, their challenges seem to divide academia with some scholars attributing these challenges to how they allocate and manage their resources and not necessarily the relevant funding support (see the conclusions of Logli, 1981 versus Bosa, 1961; Levy, 1993; and Keasey \& Watson, 1994).

Underlying the respective business management or funding support challenge is perhaps, the relevant educational background and the prevailing level of poverty in the country. For instance, as a developing country, Ghana generally, suffers from significant evidence and incidence of both poverty and illiteracy. The country is geographically demarcated and administratively governed by ten (10) regions. The regions are similarly governed and the Central Region, like the others, has further been geographically divided and governed by twenty (20) areas either in the form of district, municipal or metropolitan depending, among others, on the population, administrative set-up and so on. Indeed, small and micro businesses of various industries (markets or sectors) are duly represented in the region. Each demarcated area has a chief executive appointed by the President of the Republic of Ghana. According to the Ghana Statistical Service (GSS), the Central Region is the fourth poorest region in Ghana (GSS, 2002). This study generally, looks at the financial management practices of the small and micro businesses in Ghana with specific evidence from the Central Region.

Significance of the Study

SMEs are of crucial importance to every economy in the specific impacts of economic growth and employment creation, especially, the specific communities in which they operate or exist. Their impacts are felt in the form of taxation and other levies, a source employment for the unemployed as well as the provision of essential products and services respectively to the citizenry. As such, problems or challenges militating against their development and growth have both direct and indirect effects on every stakeholder and as expected, where a problem has been identified, it becomes incumbent on every stakeholder to play a part. But, it appears these businesses have several problems at the moment and may need to be specifically identified one after the other in order to properly address them in turns. Indeed, the problem of resource allocation and management has long been documented (see Logli, 1981).The business owners perhaps have their agreements and disagreements respectively, with some of the purported challenges they face as assigned by other interested parties. Government agencies and departments as well as NGOs directly involved, with the mandate to assist in addressing the problems may be doing their best, depending on the relevance of the problem so identified and the solution(s) applied. In the meantime, in Ghana, it is estimated that over $60 \%$ of new businesses fail within five years and as expected, the small business manager would need to have experience and knowledge in the field one wants to enter (Boachie-Mensah \& Marfo-Yiadom, 2005). Furthermore, they maintain that managerial inexperience in most small businesses is identified as the major problem of the failing enterprises. This study attempts to obtain first-hand information from the business owners themselves on their financial management practices in order to situate their associated problems in line with relevant theory in this regard for appropriate recommendations. The findings are equally expected to clarify the exact financial management problem(s) the businesses face for further research focus.

\section{Objectives of the Study}

The objectives were to:

- Obtain the understanding of financial management, its processes and actions by the selected owner-managers;

- Highlight the nature of small and micro enterprises in Ghana;

- Obtain the understanding of financial management practices by the selected enterprise owners and relate these to relevant theory;

- Ascertain the challenges, if any, with the existing practices by the owner-managers;

- Offer options to remedy poor practices and to improve upon good practices; and

- Suggest areas for future policy and research directions accordingly.

\section{Literature Review}

The review considers related relevant documentation on small and micro businesses generally, the same as the case maybe in the Ghanaian context, financial management and related prior studies.

\subsection{Small and Micro Businesses}

Small or micro businesses have been defined in many ways. However, in all these, there are common features. These include the fact that regardless of one's continent, development status and/or currency, small or micro businesses employ relatively fewer persons and are characterized by a relatively small amount of start-up and working capital as well as turnover (Mbroh \& Assah, 2015). For instance, in the UK, the Bolton Committee's report defined these by emphasizing on "economic" and "statistical" perspectives. Under the "economic" definition a firm is regarded as small if it meets the following three criteria: (1) It has a relatively small share of their market place; (2) It is managed by owners or part-owners in a personalized way 
and not through the medium of a formalized management structure; and (3) It is dependent, in the sense that it does not form part of a large enterprise. Equally, the "statistical" definition had three criteria as follows: (1) Quantifying the size of the small firm sector and its contribution to GDP, employment, export and so on; (2) comparing the extent to which the small firm sector's economic contribution has changed over time; and (3) Applying the statistical definition in a cross-country comparison of the small firm's economic contribution (Bolton, 1971).

Nigeria is Africa's most populous nation from which Oshagbemi (1985) reports that the main criteria used throughout the world to describe small businesses include: sales value; number of employees; financial strength; relative size; initial capital outlay; comparison with its past standards; independent ownership; and type of industry.

In their view, Wynarczyk, et al (1993) identified the characteristics of a small firm other than size by arguing with three ways of differentiating between small and large firms as follows: (1) Uncertainty associated with being a price-taker; (2) Limited customer and product base; and (3) Uncertainty associated with greater diversity of objectives as compared to large firms. According to UNIDO (1999), firms in developing countries based on the number of workers as follows: Large (firms with 100+ workers); Medium (firms with 20-99 workers); Small (5-19 workers); and Micro, defined as employing between 1 to 5 workers. On their part, the UNCTAD (2000) defines a micro business as:

"A business involving one to five persons (typical of a sole trader). Its character would be such that its activities are simple enough to be managed directly on a person-to-person basis and the scale of the operations means it is unlikely to need or be able to afford to devote significant staff time to accounting. Its operations are likely to concern a single product, service or type of operations. Only basic accounting is needed to record turnover, control expenses and profitability and if necessary, compute profits for tax purposes. It is unlikely to have extensive credit transactions".

A small business is defined as:

"A business employing 6 to 50 persons. Such a business would probably have several lines of activity and conceivably more than one physical location. It would probably need loan finance and have to report to lenders. Its payroll would potentially be quite large and relatively complex and it would need management information on turnover and costs analysed by product line. It would potentially do a substantial proportion of its business on credit. It would therefore need a more sophisticated accounting and control system, but probably without having to consider issues such as pensions, provisions, leases and financial instruments. It would probably need a full-time book-keeper to maintain records and information flow to management" (UNCTAD, 2000).

\subsection{Small and Micro Businesses in a Ghanaian Context}

In Ghana, the National Board for Small Scale Industries (NBSSI) is the apex body established by Act of Parliament
(Act 434 of 1981) with the tasks of promoting small scale industries. In its categorization of business units, it considers "small enterprises as those which have 29 and not less 6 employees and enterprises whose capital investment requirements do not exceed the cedi equivalent of USD100,000 or its equivalent". Again, "enterprises employing up to 5 persons with a total fixed assets of not more than USD10,000 or equivalent is a micro business" (NBSSI, 2000). Indeed recent research has played a significant role. For instance, a small business owner (SBO) is a person who establishes and manages a business to attain personal objectives and sees the business as an extension of his or her needs, goals and personality since growth might not be such a person's major objective (Boachie-Mensah \& Marfo-Yiadom, 2005).Accordingly, Mbroh (2011) noted that:

"...the nature of small businesses in Ghana is that they are often simply registered with the District, Municipal or Metropolitan Assembly, the Ghana Revenue Authority for income tax compliance and where applicable, the VAT. In addition, the well-established ones are registered with the registrar General's Department. The owner/manager who often doubles as the financial manager is charged with the day-to-day management of cash. This function includes the handling of cash receipts in the manner of safe-keeping, depositing at the bank and control over disbursements. Others include investing idle cash and necessary planning to maintain safe cash levels at all times".

However, for the purposes of this study, a micro business is a registered business employing up to 5 persons or having a capitalization of not more than USD10,000 or its equivalent. For similar purposes, a small business is taken as a registered business employing between 6 and 29 persons or having a capitalization of not more USD100,000 or its equivalent (see Mbroh \& Assah, 2015).

\subsection{Finance, Management and Financial Management}

Financial management is a term involving two technical words - finance and management, as such; it may be useful to begin with an understanding of both words in the term. Finance is the body of facts, principles and theories relating to raising and using money by individuals, businesses and governments (Marfo-Yiadom, 2009). It is also about money and sources as well as about people. The success of a business depends on how well it harnesses everyone to work to the common end, and as expected the financial manager must appreciate the conflicting objectives often encountered in financial management (Brealey \& Myers, 2003). Literally, to finance something means to provide and allocate financial input or support and to monitor the outcome. According to Maness (1988), finance is the study of acquisition and investment of cash for the purposes of enhancing value and wealth. Even though, three perspectives including personal and public finance exist, business or corporate finance would be emphasized for the purposes of this study. In their view, Ross et al (2004) noted that "business finance is the study of ways to answer the following three questions: 1. What longterm investments should you take on? That is, what lines of 
business will you be in and what sorts of buildings, machinery, and equipment will you need?; 2. Where will you get the long-term financing to pay for your investment? Will you bring in other owners or will you borrow the money?; and 3. How will you manage your everyday financial activities such as collecting from customers and paying suppliers?"

On the other hand, the term management is defined as making things happen through strategic and entrepreneurial leadership (Carpenter et al, 2010). It is the attainment of organisational goal in an effective and efficient manner through planning, organising, leading and controlling organisational resources (Daft, 2012).

How the finance issues are handled is the concept or theory of financial management (alternatively called corporate finance, business finance or managerial finance).Financial management is viewed as one of the essential areas in business activities due to the fact that the survival, growth and expansion of the business can only be achieved where sound financial management practices are in operation in consonance with the overall business objectives (Attom \& Mbroh, 2012). According to Baker (1991), financial management is a decision-making process concerned with planning, acquisition and utilization of funds in a way that achieves the firm's desired goals. Pinches (1990) noted that it is the management and financing of resources for firms by means of money, with due regard for prices in external economic markets. In a similar view, Maness (1988) maintains that it deals with the proper acquisition of cash and the efficient allocation of that cash within the business. In the words of McMenamin (1999), financial management may simply be defined as 'the ways and means of managing money' but more formally; it is the determination, acquisition, allocation, and utilization of financial resources, usually with the aim of achieving some particular goals or objectives. Financial management is concerned with the acquisition, financing, and management of assets with some goal in mind (Van Horn \& Wachowicz, Jr., 2008).

\subsection{Prior Studies on Financial Management in Small and Micro Enterprises in Ghana}

Several studies have been conducted on aspects of financial management practices by small and micro enterprises (SMEs) in Ghana. Some have been in the area of cash management since it is widely that cash is the lifeblood of the enterprises. For instance, in his survey of cash management practices of selected firms, Marfo-Yiadom (2002) concluded among others, that $95 \%$ of his respondents maintained some system of cash management, however inappropriate, with $43 \%$ of them having not made short-term investment within the preceding year (see also (Mbroh, 2012b; and Attom, 2013).Others have focused on the funding sources and the associated difficulties faced by the SMEs in this respect. To this end, Eyiah (2001) observed that the main problem with small business owners face is finance, as currently the commercial banks operate devoid of good knowledge of their needs as they perceive the small businesses and their owners as high risk and unprofitable. Related conclusions by Mbroh (2012a); Addai (1999); and Logli (1981) are worth mentioning. Again, recent conclusions of studies (Mbroh \& Assah, 2015; and Mbroh \& Quartey, 2015) on financial records-keeping and business decision-making practices as well as on stage-by-stage funding sources and challenges respectively of the small and micro businesses are equally relevant to this study. In their view, Boachie-Mensah and Marfo-Yiadom (2005), also noted that in Ghana, it is estimated that over $60 \%$ of new businesses fail within five years with their assigned reasons being managerial incompetence, lack of experience and poor financial control.

This study rather places emphasis on the concept of financial management by considering the related practices involving finance acquisition (sources), utilization (business operations) and investments (short, medium and/or long-term) by the selected enterprises.

\section{The Conceptual Framework}

The study has adapted (with appropriate modification or reconstruction), a framework of cash flow between financial markets and the firm's operations projected by Brealey and Myers (2003) as shown in figure lbelow. The demonstrational keys of this framework are: (1) Cash raised by selling financial assets to investors; (2) Cash invested in the firm's operations and used to purchase real assets; (3) Cash generated by the firm's operations; (4a) Cash reinvested; and $(4 b)$ Cash returned to investors.

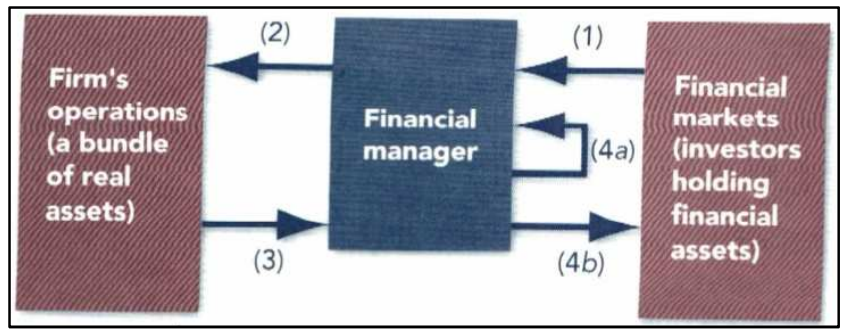

Source: Brealey and Myers (2003, p.6).

Fig. 1. Flow of cash between financial markets and the firm's operations.

Consequent to the above, figure 2(below) represents the related relevant reconstruction showing the flow of funds between the providers or sources of finance (to the enterprises) and the respective enterprise's operations. The keys to reconstructed figure are: (1) Cash and other financial resources raised from several applicable sources of funds to the respective enterprise. Relating to both start-up and subsequent funding, these sources are mainly in the form of: equity (owner's personal funds and those from family members as well as friends); and debt (funds obtained externally from commercial banks, private financial institutions, corporate investors, hire purchase, savings and loans schemes, and such others). However, the funds availability and quantum may be determined, among others, by the enterprise's goodwill and the extent of trust placed in 
its strategies, the owner-manager's personal contacts, goodwill and financial management skills including financial planning; (2) Cash and other financial resources utilized or allocated in the form of fixed and working capitals as well as short/medium/long-term investments in line with the enterprise's strategic operations. Again, the owner-manager's personal experience and financial management skills in financial controls and of value creation (addition) would be paramount; (3) Cash and other financial resources generated by the respective enterprise's operations. The level of these resources, to a greater extent, would be influenced by the inherent accuracy of both planning and of decisions made, perhaps further based on the owner-manager's understanding of issues; (4a) Cash and other financial resources duly reinvested or ploughed back into the enterprise's operations. This may require sharp and proper investment appraisal skills as well as the extent of understanding and reliance on the financial advice sought in this regard; and (4b) Cash and other financial resources (in the form of loans) returned to investors (external sources) or taken as drawings by the enterprise owner. The relevant repayment amounts, frequency, duration and/or financial effect may be determined by the respective enterprise's outlook, owner-manager's personal goodwill, contacts and persuasive financial management skills.

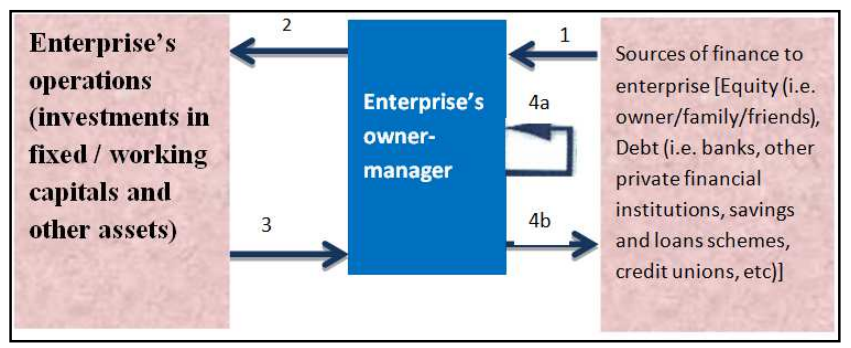

Source: Authors' adaption and construct, April 2015.

Fig. 2. Flow of finance between providers of finance and the enterprise's operations.

\section{Methodology}

The study was conducted on SMEOs within the Central Region of Ghana. There are no reliable data on the number of SMEOs in the region. For this reason, the study adopted the administrative demarcation of the region since it fairly represents the general dynamics in the form of population size, state of infrastructure, volume of commerce, and the concentration of the defined business units. Specifically, the district capitals of the twenty (20) administrative areas were used (Mbroh \& Quartey, 2015). The study initially tested the questionnaire and based on the responses, the final questionnaire was produced and administered. The questions included the respective enterprise owner's years in business (business experience), their academic or professional backgrounds, gender differences in these respects, their extent of financial management understanding with respect to the outlined conceptual framework, relevant peculiarities with regards to business segment differences, sources as well as challenges and known financiers (external sources) in these respects. Also asked, was their main financial management challenge(s) and the suggested way forward. Using a purposive sampling technique, the responses were collected were collected via a self-administered questionnaire. However, there were few, perhaps isolated cases where for reasons of illiteracy, an interview schedule was used.

For the purposes of uniformity in the response gathering, five research assistants went into each district capital in a day mainly with the intention to self-administer questionnaires on those enterprise owner-managers who were available and were willing to respond or be interviewed. The respondents were selected on the basis that they were owner-managers of the respective enterprises. The same team administered the questions in all the twenty capitals. A careful consideration of the differences or peculiarities in the business industries or sectors had been made. This is obviously, a form of purposive sampling where a minimum of 150 respondents would be considered acceptable for the sample and consequently, the study's conclusion (see also Mbroh \& Quartey, 2015).

A total of 500 questionnaires were made available for the 20 district capital towns but the team was able to administer 372. For the purposes of this study, a SME is selected if the respective respondent's business unit is registered with the Registrar of Companies, owner-managed and the business satisfies any of the following conditions during the reconnaissance survey:

- Employs between 1 and 29 people;

- Has a total fixed assets value between GHS80,000 and GHS200,000 (or USD 20,000 and USD50,000); and

- Has an annual turnover between GHS20,000 and GHS300,000 (or USD5,000 and USD 75,000).

Assumptions and Hypotheses

The assumptions underlying the study are:

- The sampled SMEs are representative enough to enable the researchers come to a reasonable conclusion of the study;

- Most of the SMEOs surveyed do not understand the financial management concept and its challenges in businesses; and

- The government of Ghana and other stakeholder groups of the defined business units have designed private sector business management capacity programmes for the SMEOs, but not all owners have benefited.

\section{Results and Analysis}

\subsection{Demographic and Related Responses}

Overall, 372 respondents made up of 118 small and 254 micro business owner-respondents respectively. Experience is crucial in every endeavour. Specifically in businesses, it is expected that the longer a business owner runs his or her business, the more experienced he/she would be in properly managing all business situations including that of financial 
management. Again, common knowledge is that the term short-term refers to a period up to one year; medium-term is between one and three years with periods beyond three years being classified as long-term. Based on this principle, Table 1 shows that majority $(81.2 \%)$ of the respondents may be classified as already being in their long-term business management stage (over 3 years). Also, regardless of a business size, industry participation or segment, the ownermanager is expected to have attained a reasonable level of education to adapt proactively to the financial management issues. The results (Table 2) show that overall, majority (68\%) of the respondents have had reasonable academic backgrounds. However, a significant proportion (13\%) had not had any form of education. Already in Ghana, many have attributed the sudden collapse and to a greater extent, the problems faced by these businesses to lack of relevant management knowhow. For instance, Boachie-Mensah and Marfo-Yiadom (2005), noted that in Ghana, it is estimated that over $60 \%$ of new businesses fail within five years with their assigned reasons being managerial incompetence, lack of experience and poor financial control.

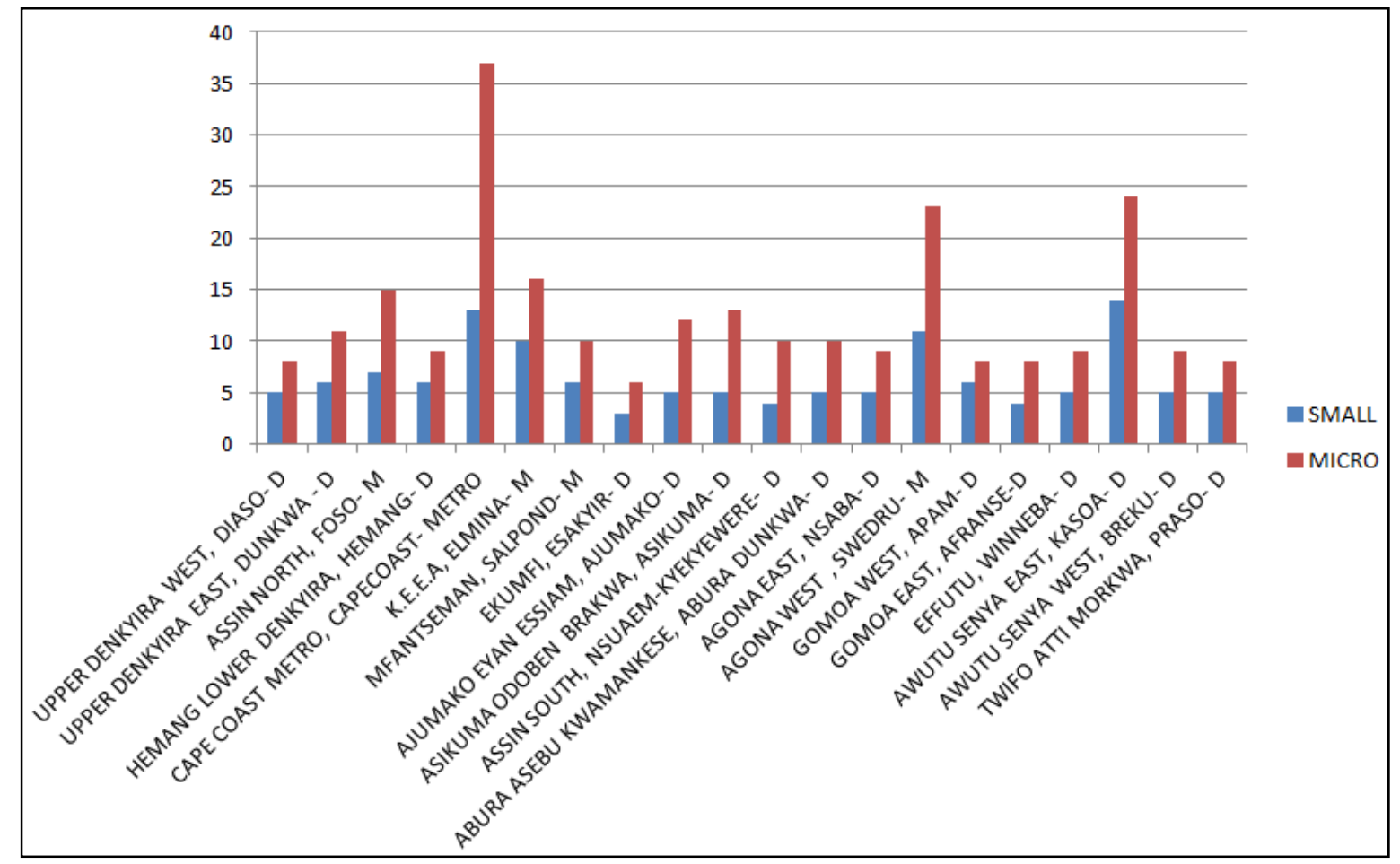

Fig. 3. Response per district participation and business segment.

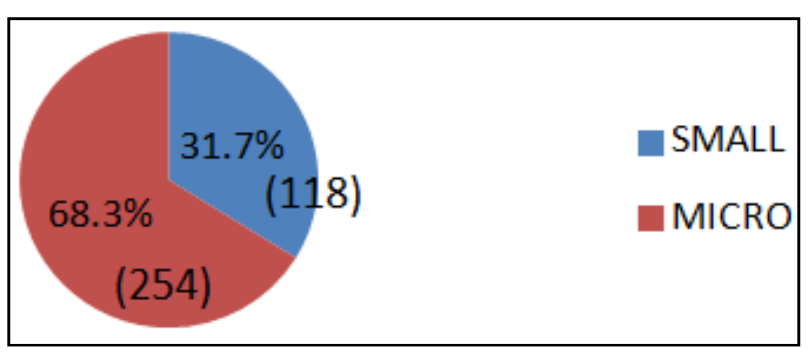

Fig. 4. Participation by Business Segments.

Table 1. Owner-manager's experience or years in business:

Number of years in business

\begin{tabular}{llllll}
\hline & $\begin{array}{l}\text { Up to } \\
\mathbf{1 y r}\end{array}$ & $\mathbf{1 - 3 y r s}$ & $\mathbf{3 - 5 y r s}$ & $\begin{array}{l}\text { Above } \\
\text { 5yrs }\end{array}$ & $\begin{array}{l}\text { Row } \\
\text { Total }\end{array}$ \\
\hline Small & $33.3(10)$ & $28.0(12)$ & $26.3(26)$ & $35.0(70)$ & $31.7(118)$ \\
Micro & $66.7(20)$ & $72.1(31)$ & $73.7(73)$ & $65.0(130)$ & $68.3(254)$ \\
\hline $\begin{array}{l}\text { Sample } \\
\text { size } \\
(\% / f)\end{array}$ & $8.1(30)$ & $11.6(43)$ & $27.4(99)$ & $53.8(200)$ & $100(372)$ \\
\hline
\end{tabular}

Source: Authors' Field work, April 2015
Table 2. SMEOs'educational background:

Business segment(f/\%)

\begin{tabular}{llll}
\hline Level of education & Small & Micro & Row Total \\
\hline None & $10.2(12)$ & $14.2(36)$ & $12.9(48)$ \\
JHS/MSLC/Primary & $14.4(17)$ & $20.0(51)$ & $18.3(68)$ \\
RSA/O'/' A' Level/ & $29.7(35)$ & $37.8(96)$ & $35.2(131)$ \\
DBS/SHS & $9.3(11)$ & $8.3(21)$ & $8.6(32)$ \\
HND/Degree & $15.3(18)$ & $9.1(23)$ & $11.0(41)$ \\
Masters and above & $21.2(25)$ & $10.6(27)$ & $14.0(52)$ \\
Professional & & & $100(372)$ \\
\hline (eg.MD/ICA/ING.) & $31.7(118)$ & $68.3(254)$ & \\
\hline Sample size(\%/f) & & &
\end{tabular}

Source: Authors' Field work, April 2015.

\subsection{SMEOs'Basic Working Knowledge in Financial Management}

Education enhances the efficiency with which human efforts are expended. It provides the relevant knowledge and skills to properly understand and execute tasks respectively. In fact, without the relevant education, certain tasks may, at 
best, be poorly carried out. Proper financial management requires both special knowledge and/or relevant skills, not necessarily one's formal educational background but relevant educational and professional (experience) training. This due the fact that there are several dynamics involved in financial management and it is expected that with the relevant training and experience a business owner would better understand the relevant issues in order to respond appropriately for the desired results. All told, special training may be required to properly carry out this function, especially those without relevant business educational backgrounds. Table 3 shows the results on the SMEOs' basic working knowledge in financial management. Overall, majority (39\%) of the respondents have neither reasonable (or relevant) level education nor the appropriate training. Again, 31\% of them have never had any business-related education, with about $30 \%$ who have either had business education or relevant business (financial) management training of some sort.

Table 3. SMEOs' basic working knowledge in business / financial management

Business segment(f/\%)

\begin{tabular}{llll}
\hline Response & Small & Micro & Row Total \\
\hline I don't have business & $39.0(46)$ & $27.5(70)$ & $31.2(116)$ \\
training & $29.7(35)$ & $14.6(37)$ & $19.4(72)$ \\
I studied business at college & $14.4(17)$ & $8.3(21)$ & $10.2(38)$ \\
I have sought training now & $16.9(20)$ & $49.6(126)$ & $39.2(146)$ \\
None of the above & $31.7(118)$ & $68.3(254)$ & $100(372)$ \\
\hline Sample size(\%/f) &
\end{tabular}

Source: Authors' Field work, April 2015.

\subsection{Industry and Gender Participation of Respondents}

A business industry refers to the core business or service offered by businesses. Where particular businesses offer the same or similar core business or service, then these businesses are said to be in the same business industry or sector. Fact is that every business exists in a particular industry, regardless of the size or segment (Mbroh \& Quartey, 2015). Similarly, Mbroh and Attom (2012) observed that some industries are much more competitive than others depending on factors relating to entry, market share and growth. That, the higher the number of businesses in a given industry, the higher the level of competition a business faces in the respective industry, needless to say that there is competition in every business industry. In businesses, they however continued, competition is fought with the relevant efficient sharp strategies upon cost-benefit-analysis. Fact is that, crucial to being efficient in cost-benefit strategies is the application of the relevant financial management skills and knowhow. Table 4 shows that overall, the food, beverage and tobacco industry dominated $(15.3 \%)$, followed by the education sector (12.4\%). However, within the small business segment, the education sector dominated (20\%), followed by that of hospitality $(12 \%)$. The micro businesses had the food, beverage and tobacco sector as dominant (19\%), followed by the building, welding, metal and construction sector $(13 \%)$.

Even though, the study did not focus on gender specifics with respect to respondents educational background, relevant business experience (years in business) and so on, Mbroh and Assah (2015) had concluded that there are more females $(53 \%)$ in the micro business segment and more males $(60 \%)$ in the small business segment in Ghana. This is confirmed by the results in Table 5, where overall, $47 \%$ of respondents were females; $53 \%$ were males but in the small business segment females represented 37\% and 63\% were males. On the micro business side, females were $52 \%$ and males, $48 \%$.

Table 4. Industry participation by SMEO:

Business segment(f/\%)

\begin{tabular}{llll}
\hline Type of industry & Small & Micro & Row Total \\
\hline Batique,Garment\&Textiles & $5.9(7)$ & $10.2(26)$ & $8.9(33)$ \\
Building, welding/metal/const & $11.0(13)$ & $12.6(32)$ & $12.1(45)$ \\
Timber processing & $8.5(10)$ & $7.9(20)$ & $8.1(30)$ \\
Printing \& Paper products & $6.8(8)$ & $11.0(28)$ & $9.6(36)$ \\
Food, beverage \&tobacco & $8.5(10)$ & $18.5(47)$ & $15.3(57)$ \\
Hospitality & $11.9(14)$ & $6.3(16)$ & $8.1(30)$ \\
Automotive product/ services & $7.6(9)$ & $5.5(14)$ & $6.2(23)$ \\
Education(1st \& 2 ${ }^{\text {nd }}$ cycles) & $19.5(23)$ & $9.1(23)$ & $12.4(46)$ \\
Soap production & $4.2(5)$ & $5.1(13)$ & $4.8(18)$ \\
Leather, rubber \&plastics & $6.8(8)$ & $9.5(24)$ & $8.6(32)$ \\
Herbal, medicine/pharmacy & $9.3(11)$ & $4.3(11)$ & $5.9(22)$ \\
\hline Sample size(\%/f) & $31.7(118)$ & $68.3(254)$ & $100(372)$ \\
\hline
\end{tabular}

Source: Authors' Field work, April 2015.

Table 5. SMEOs' gender distribution:

Business segments

\begin{tabular}{llll}
\hline Gender & Small & Micro & Row Total \\
\hline Female & $37.3(44)$ & $51.6(131)$ & $47.0(175)$ \\
Male & $62.7(74)$ & $48.4(123)$ & $53.0(197)$ \\
\hline Sample size(\%/f) & $31.7(118)$ & $68.3(254)$ & $100(372)$ \\
\hline
\end{tabular}

Source: Authors' Field work, April 2015.

\subsection{Business Owners' Understanding of the Financial Management Concept}

Financial management is not all about cash management. In fact, it is broader and much more demanding than merely managing cash. It involves the processes that answer questions such as: Which project, service or product is to be undertaken? How much would be needed? Which source(s) or which party should provide the needed funds and why? When must the funds be ready? How would the fund be received and disbursed? Which officers would be directly involved in the transactions? How much is expected as returns and so on. In support, Ross et al (2004) noted that "business finance is the study of ways to answer the following three questions: 1. What long-term investments should you take on? That is, what lines of business will you be in and what sorts of buildings, machinery, and equipment will you need?; 2. Where will you get the long-term financing to pay for your investment? Will you bring in other owners or 
will you borrow the money?; and 3. How will you manage your everyday financial activities such as collecting from customers and paying suppliers?"

It is expected that SMEOs' with reasonable understanding of the concept are likely management their businesses well since their financial decisions would be based on solid scientific justification. Conversely, SMEOs' without the relevant financial management understanding are expected to survive on mere business luck since they would obviously lack the relevant knowledge and skills in what they do. The results (Table 6) show that overall, only $13 \%$ of the respondents actually understood the meaning of financial management. Indeed, regardless of the business segment, majority (36\%) of the respondents believed that maintaining proper financial records was all about financial management. Really worrying is the fact that $13 \%$ of overall respondents stated that they did not understand the meaning of financial management.

Table 6. SMEOs' understanding of financial management:

Business segment $(\% / f)$

\begin{tabular}{llll}
\hline $\begin{array}{l}\text { Understanding } \\
\text { response }\end{array}$ & Small & Micro & Row Total \\
\hline $\begin{array}{l}\text { To manage or control } \\
\text { the finances }\end{array}$ & $15.3(18)$ & $25.2(64)$ & $22.0(82)$ \\
$\begin{array}{l}\text { To properly account for } \\
\text { cash spent }\end{array}$ & $8.5(10)$ & $7.8(20)$ & $8.1(30)$ \\
$\begin{array}{l}\text { To acquire, control } \\
\text { \&utilise funds }\end{array}$ & $24.6(29)$ & $7.5(19)$ & $12.9(48)$ \\
$\begin{array}{l}\text { To operate business } \\
\text { bank account }\end{array}$ & $7.6(9)$ & $8.7(22)$ & $8.3(31)$ \\
$\begin{array}{l}\text { To maintain proper } \\
\text { financial records }\end{array}$ & $38.1(45)$ & $34.3(87)$ & $35.5(132)$ \\
$\begin{array}{l}\text { Don't know the } \\
\text { meaning }\end{array}$ & $5.9(7)$ & $16.5(42)$ & $13.2(49)$ \\
\hline Sample size $(\% / \mathrm{f})$ & $31.7(118)$ & $68.3(254)$ & $100(372)$ \\
\hline
\end{tabular}

Source: Authors’ Field work, April 2015.

\subsection{Financial Management Practices by the SMEOs}

Although, an efficient financial management involves several activities either carried out step by step or simultaneously. At best, each of these activities may be described as a financial management function and therefore individually, they do not represent the full functions of financial management. In other words, any practice or function short of that is inadequate. In line with the study's conceptual framework, McMenamin (1999), stated that financial management may simply be defined as 'the ways and means of managing money' but more formally; it is the determination, acquisition, allocation, and utilization of financial resources, usually with the aim of achieving some particular goals or objectives. In support, Van Horn and Wachowicz, Jr. (2008) observed that financial management is concerned with the acquisition, financing, and management of assets with some goal in mind. The results (Table 7) show that the respondents have mainly practiced cash book and other book-keeping functions in lieu of proper financial management practices. This raises some questions about the $13 \%$ who had indicated that they understood the meaning of financial management. Also worrying is the $12 \%$ of respondents who indicated their practice based on 'personal experience and/or strategy' of some sort in lieu of the concept.

Table 7. Existing financial management practices by SMEOs:

Business segment $(\% / f)$

\begin{tabular}{llll}
\hline $\begin{array}{l}\text { Understanding } \\
\text { response }\end{array}$ & Small & Micro & Row Total \\
\hline $\begin{array}{l}\text { Record cash receipts } \\
\text { and payments }\end{array}$ & $17 .(21)$ & $41.7(106)$ & $34.1(127)$ \\
$\begin{array}{l}\text { Cash book records } \\
\text { every activity }\end{array}$ & $11.0(13)$ & $10.2(26)$ & $10.5(39)$ \\
$\begin{array}{l}\text { Operate business bank } \\
\text { account }\end{array}$ & $19.5(23)$ & $5.1(13)$ & $9.7(36)$ \\
$\begin{array}{l}\text { Pay expenses/debts } \\
\text { without delay }\end{array}$ & $14.4(17)$ & $11.8(30)$ & $12.6(47)$ \\
$\begin{array}{l}\text { Maintain proper } \\
\text { financial records }\end{array}$ & $29.7(35)$ & $16.9(43)$ & $21.0(78)$ \\
$\begin{array}{l}\text { I use personal } \\
\text { experience/strategy }\end{array}$ & $7.6(9)$ & $14.2(36)$ & $12.1(45)$ \\
\hline Sample size $(\% / f)$ & $31.7(118)$ & $68.3(254)$ & $100(372)$ \\
\hline
\end{tabular}

Source: Authors' Field work, April 2015.

\subsection{SMEOs' Financial (Management Skills) Decision- Making}

Adequate skills aid in relevant decision-making. In order to practice proper financial management, the SMEOs are expected to acquire adequately related knowledge and skills. Alternative to the above (results in Table 7) the enterprise owners were asked about specific thoughts and decisions they considered and took respectively in line with efficient financial management. The responses (Table 8) are evident that the enterprise owners had made decisions based on deep financial management (implications) thoughts, especially, majority of the small enterprise segment. In contrast, majority of the micro enterprise owners gave dismissive responses, perhaps conventional practices, in this regard. Seeming haphazard way of practice, it appears dangerous, how the respective micro enterprises would survive and possibly grow into, at least, the small business segment (see the conclusions of Nthejane, 1997).

Table 8. SMEOs' financial (management skills) decision-making:

Business segment $(\% / f)$

\begin{tabular}{|c|c|c|c|}
\hline $\begin{array}{l}\text { Considerations/decisions } \\
\text { involved }\end{array}$ & Small & Micro & Row Total \\
\hline Identifying sources of finance & $31.3(37)$ & $7.1(18)$ & $14.8(55)$ \\
\hline $\begin{array}{l}\text { Selecting wealth-enhancing } \\
\text { sources }\end{array}$ & $11.9(14)$ & $1.2(3)$ & $4.6(17)$ \\
\hline Considering cost of capital & $6.8(8)$ & $2.0(5)$ & $3.5(13)$ \\
\hline $\begin{array}{l}\text { Ownership (control) } \\
\text { compromise }\end{array}$ & $8.5(10)$ & $\mathrm{n} / \mathrm{a}$ & $2.7(10)$ \\
\hline $\begin{array}{l}\text { Investment appraisal/resource } \\
\text { allocation }\end{array}$ & $14.4(17)$ & $\mathrm{n} / \mathrm{a}$ & $4.6(17)$ \\
\hline Financial planning (budgeting) & $7.6(9)$ & $\mathrm{n} / \mathrm{a}$ & $2.4(9)$ \\
\hline $\begin{array}{l}\text { Decisions on which } \\
\text { product/service }\end{array}$ & $10.2(12)$ & $2.8(7)$ & $5.1(19)$ \\
\hline Business is all about luck & $\mathrm{n} / \mathrm{a}$ & $35.0(89)$ & $23.9(89)$ \\
\hline
\end{tabular}




\begin{tabular}{llll}
\hline $\begin{array}{l}\text { Considerations/decisions } \\
\text { involved }\end{array}$ & Small & Micro & Row Total \\
\hline $\begin{array}{l}\text { I use any available } \\
\text { source/resource }\end{array}$ & $6.8(8)$ & $34.6(88)$ & $25.8(96)$ \\
$\begin{array}{l}\text { I use personal } \\
\text { experience/strategy }\end{array}$ & $2.5(3)$ & $17.3(44)$ & $12.6(47)$ \\
\hline Sample size (\%/f) & $31.7(118)$ & $68.3(254)$ & $100(372)$ \\
\hline
\end{tabular}

Source: Authors' Field work, April 2015.

\subsection{Identifying and Dealing with the Sources of Finance}

In Ghana, there are several sources of finance to the SMEOs in the form of equity and debt (see Boachie-Mensah \& Marfo-Yiadom, 2005; and Mbroh \& Quartey, 2015). However, each of these sources may require of the SMEO, unique attention in the form condition(s) and approach. In view of this, it is incumbent of the respective enterprise owner to identify these sources in attempt to screen them on the basis of their focus, terms and conditions, and most importantly, their extent of reliance. To this end and in line with the enterprise's outlook in terms of operational volume, competitive and growth strategies, financial needs and availability, associated cost burden, respective cost and terms of borrowing, financial capacity to repay loans, and such others, financial management skills will enable the SMEO to carefully evaluate each of the available sources of finance. When this screening is properly done it enables the owner to select the sources that are suitable to the needs of the enterprise in question. However, the first step in this endeavour, is how (financial management thoughts and skills) to identify these sources of finance. Table 9 shows results on how the owners identify the various sources of finance available to their enterprises. Overall, majority (42\%) of the respondents maintained that they found the sources through follow-ups on media reports and adverts. However, majority $(36 \%)$ of the small enterprise owners stated that they rely on their personal connections and contacts. Many (52\%) of the micro enterprise owners maintained that they followed-up on media reports and adverts to list the funding sources available to their businesses.

Table 9. How the available sources of finance are identified:

Business segment (\%/f)

\begin{tabular}{llll}
\hline How sources are identified & Small & Micro & Row Total \\
\hline $\begin{array}{l}\text { Informed by union leaders } \\
\text { (CoC) }\end{array}$ & $16.1(19)$ & $3.1(8)$ & $7.3(27)$ \\
$\begin{array}{l}\text { Personal connections and } \\
\text { contacts }\end{array}$ & $36.4(43)$ & $10.2(26)$ & $18.5(69)$ \\
$\begin{array}{l}\text { Outreach work by } \\
\text { agencies/NGOs }\end{array}$ & $12.7(15)$ & $5.1(13)$ & $7.5(28)$ \\
$\begin{array}{l}\text { Routine enquiries / checks } \\
\text { Follow-up on media } \\
\text { reports/adverts }\end{array}$ & $4.2(5)$ & $12.2(31)$ & $9.7(36)$ \\
$\begin{array}{l}\text { I use banks and savings } \\
\text { \&loans }\end{array}$ & $19.5(23)$ & $52.0(132)$ & $41.7(155)$ \\
$\begin{array}{l}\text { I hate (don't like) loans/debt } \\
\text { finance }\end{array}$ & $11.0(13)$ & $11.8(30)$ & $11.6(43)$ \\
\hline Sample size (\%/f) & $31.7(118)$ & $68.3(254)$ & $100(372)$ \\
\hline
\end{tabular}

Source: Authors' Field work, April 2015.

\subsection{Selecting the Sources of Finance; Utilizing (Allocating) the Funds; and Dealing with the Returns Produced by the Firm's Operations}

Understanding the concept of financial management enables one to deal properly with all the stages in the process. Indeed, financial management is not about a single output decision but multiple dependent input decisions. In line with the conceptual framework, selecting the relevant source(s) implies that after assessing a particular source, the owner has duly accepted to use it and/or has sought financial assistance for the operations of the business. Thereafter, the obtained cash or financial resources may be utilized or allocated in the form of fixed and working capitals as well as short/medium/long-term investments in line with the enterprise's strategic operations. Again, the respective SMEO's personal experience and financial management skills in financial controls and of value creation (addition) would be paramount. Table 10 shows results on factors considered in selecting the relevant sources of finance by the SMEOs. Overall, the first three leading considerations were: the use of any available source of capital; capacity to repay bearing in mind the uncertainties with operational volume (business trends); and the possible effects on cash or liquidity levels. There were differences in the business segment responses. Rather, the small business respondents used proper financial management (scientific) indicators to select their sources of finance, whereas, the micro business respondents had significantly adopted conventional methods in this exercise. Again, these micro business practices pose serious implications and threats to the respective businesses' survival and consequently, their going-concern dreams. It should be noted that if proper indicators are not used as basis of selecting and contracting loans (funding), the associated benefits, at best, may be very minimal due to the associated financial and other (conditional ties) costs. Commonly in such cases, the purpose for which the funding was sought may not be achieved and mostly result in repayment defaults.

Funds acquired must be based on grounded financial and operational strategic outlooks. Businesses are run proactively and such, financial planning in the form of forecasts, budgets, investment appraisal, sensitivity analysis, market research and trends, competitors' and stakeholder analysis are commonly useful. In tune with the conceptual framework, cash and other financial resources generated by the respective enterprise's operations must be prudently utilized. It is acknowledged that the level of these returns (funds), to a greater extent, would be influenced by the inherent accuracies in both the financial plans and of decisions made, perhaps, ultimately based on the owner-manager's understanding of the pros and cons. The cash and other financial resources may be reinvested or ploughed back into the enterprise's operations and when this becomes the chosen option, it may require sharp and proper investment appraisal skills as well as the extent of understanding and reliance on the financial advice sought in this regard. Alternatively, where the Cash and other financial resources (in the form of 
loans) are returned to investors (external sources) or taken as drawings by the enterprise owner, the relevant repayment amounts, frequency, duration and/or financial effect may be determined by the respective enterprise's outlook, ownermanager's personal goodwill, contacts and persuasive financial management skills. Table 11 shows the results regarding the allocation or control of funds (profits/returns) generated from the enterprise's operations. Overall, it appears that the outlook of the businesses were not convincing enough to the business owners and this resulted in only $9 \%$ of respondents who ploughed back their profits for business expansion. Disbursing as and when necessary, $7 \%$ of respondents overall, were involved with the micro business segment being the worse in that practice. Specifically, in excess of both fixed and working (ploughed back) capital, majority $(35 \%)$ of the micro business owners invested in either co-operative credit unions (susu) and treasury bills/fixed deposits, with loans repayments representing 14\% of these respondents. On the other hand, $14 \%$ of the small business owners rather invested their excess of operational returns in treasury bills/fixed deposits and $15 \%$ of their proportion servicing their debts. These investment practices, aimed at adding profit and consequently enhancing the enterprise value, are in line with theoretical framework (see Brealey\& Myers, 2003).

Table 10. Skills to prioritise available sources of finance to the enterprises Business segment $(\% / f)$

\begin{tabular}{llll}
\hline $\begin{array}{l}\text { How sources are } \\
\text { considered }\end{array}$ & Small & Micro & Row Total \\
\hline $\begin{array}{l}\text { Cost of capital } \\
\text { Effect on ownership } \\
\text { (control) }\end{array}$ & $16.9(20)$ & $7.5(19)$ & $10.5(39)$ \\
$\begin{array}{l}\text { Capacity to repay } \\
\text { (uncertainties) }\end{array}$ & $5.9(7)$ & $6.3(16)$ & $6.2(23)$ \\
$\begin{array}{l}\text { Operational volume and } \\
\text { trends }\end{array}$ & $12.7(15)$ & $13.0(33)$ & $18.3(68)$ \\
$\begin{array}{l}\text { Flexible and cheaper } \\
\text { alternatives }\end{array}$ & $7.6(9)$ & $6.3(16)$ & $8.3(31)$ \\
$\begin{array}{l}\text { Effect on liquidity(cash } \\
\text { levels) }\end{array}$ & $19.5(23)$ & $13.0(33)$ & $15.1(56)$ \\
$\begin{array}{l}\text { Luck from previous } \\
\text { source }\end{array}$ & $\mathrm{n} / \mathrm{a}$ & $5.9(15)$ & $4.0(15)$ \\
$\begin{array}{l}\text { Business is all about } \\
\text { luck }\end{array}$ & $\mathrm{n} / \mathrm{a}$ & $7.5(19)$ & $5.1(19)$ \\
$\begin{array}{l}\text { I use any available } \\
\text { source }\end{array}$ & $1.7(2)$ & $28.7(73)$ & $20.2(75)$ \\
$\begin{array}{l}\text { I use personal } \\
\text { experience/strategy }\end{array}$ & $5.9(7)$ & $5.9(15)$ & $5.9(22)$ \\
\hline Sample size (\%/f) & $31.7(118)$ & $68.3(254)$ & $100(372)$ \\
\hline
\end{tabular}

Source: Authors' Field work, April 2015.

Table 11. Key areas of financial resource allocation and control:

Business segment (\%/f)

\begin{tabular}{llll}
\hline Key areas of allocation & Small & Micro & $\begin{array}{l}\text { Row } \\
\text { Total }\end{array}$ \\
\hline $\begin{array}{l}\text { Fixed assets(building, } \\
\text { machinery,etc) }\end{array}$ & $33.1(39)$ & $15.0(38)$ & $20.7(77)$ \\
$\begin{array}{l}\text { Working } \\
\text { capital(stock,debtors,etc) }\end{array}$ & $25.4(30)$ & $15.3(39)$ & $18.5(69)$ \\
\hline
\end{tabular}

\begin{tabular}{llll}
\hline Key areas of allocation & Small & Micro & $\begin{array}{l}\text { Row } \\
\text { Total }\end{array}$ \\
\hline $\begin{array}{l}\text { Investments(T'bills, Fixed } \\
\text { deposits,etc) }\end{array}$ & $13.6(16)$ & $4.3(11)$ & $7.3(27)$ \\
$\begin{array}{l}\text { Special } \\
\text { fund(replacements,susu,etc) }\end{array}$ & $5.9(7)$ & $31.1(79)$ & $23.1(86)$ \\
$\begin{array}{l}\text { Plough back } \\
\text { profits(expansion,etc) }\end{array}$ & $4.2(5)$ & $11.8(30)$ & $9.4(35)$ \\
$\begin{array}{l}\text { Repayments(drawings,loans,etc) } \\
\text { I allocate as and when necessary }\end{array}$ & $\begin{array}{l}15.3(18) \\
2.5(3)\end{array}$ & $\begin{array}{l}14.2(36) \\
8.3(21)\end{array}$ & $\begin{array}{l}14.5(54) \\
6.5(24)\end{array}$ \\
\hline Sample size (\%/f) & $31.7(118)$ & $68.3(254)$ & $100(372)$ \\
\hline
\end{tabular}

Source: Authors' Field work, April 2015.

\subsection{SMEOs'Main Financial Management Challenge(s)}

Even though the financial management concept aims at comprehensively dealing with firms' financial matters, it may not be without challenge(s), peculiar or common. This includes practitioners with or without the relevant understanding and skills. However in practice, in order to identify the related financial management challenge(s), the competency or otherwise of practitioners are frequently brought into perspective, so as to proffer the needed remedies. Again, the challenge may either be enterprise, industry or country specific. Results in Table 12 show that even though external challenges like: unreliably poor general economic conditions; unreliable training promises by certain agencies and NGOs; business-unfriendly loans terms and conditions; and relatively high cost of borrowing were assigned, internally (overall), majority (24\%) of respondents lacked the basic working knowledge in financial management. This crucial challenge has multiplier effects on both the number and types of other challenges.

Table 12. SMEOs' main financial management challenge(s):

Business segment $(\% / f)$

\begin{tabular}{llll}
\hline How sources are considered & Small & Micro & Row Total \\
\hline $\begin{array}{l}\text { Lack of basic working } \\
\text { knowledge }\end{array}$ & $16.1(19)$ & $27.2(69)$ & $23.6(88)$ \\
$\begin{array}{l}\text { Unreliable training promises } \\
\text { Unreliable economic trends }\end{array}$ & $\mathrm{n} / \mathrm{a}$ & $6.3(16)$ & $4.3(16)$ \\
$\begin{array}{l}\text { Incapable to keep financial } \\
\text { records }\end{array}$ & $5.1(6)$ & $12.2(31)$ & $9.9(37)$ \\
$\begin{array}{l}\text { Business volume uncertainties } \\
\text { High operational costs of }\end{array}$ & $16.9(20)$ & $10.2(26)$ & $12.4(46)$ \\
$\begin{array}{l}\text { business } \\
\text { High cost of } \\
\text { capital(indiscriminate) }\end{array}$ & $10.2(12)$ & $17.3(44)$ & $15.1(56)$ \\
$\begin{array}{l}\text { Unfriendly conditions by } \\
\text { sources }\end{array}$ & $14.4(17)$ & $10.2(26)$ & $11.6(43)$ \\
Lower levels of profitability & $10.2(12)$ & $5.5(14)$ & $7.0(26)$ \\
\hline Sample size (\%/f) & $31.7(118)$ & $68.3(254)$ & $100(372)$ \\
\hline
\end{tabular}

Source: Authors' Field work, April 2015.

\section{Conclusion and Recommendations}

The results have shown how haphazard the SMEOs have conceived and practiced the crucial function of financial management. Crucial to being efficient in cost-benefit strategies is the application of the relevant financial 
management skills and knowhow. It is concluded that majority $(81.2 \%)$ of the respondents must have the necessary financial management knowhow (being in their long-term business management stage) with over 3 years of experience. Also, male owners $(63 \%)$ are more in the small businesses and their female counterparts dominate (52\%) the micro businesses. This confirms the assertion by Mbroh and Assah (2015) who found more females and males in the micro and small business segments respectively in Ghana. Overall, majority $(68 \%)$ of the respondents have had reasonable academic backgrounds. However, a significant proportion (13\%) had not had any form of education. The results are conclusive that the SMEOs lacked basic working knowledge in financial management, with an overall majority (39\%) of the respondents neither having the reasonable (or relevant) level education nor the appropriate training. Again, 31\% of them have never had any business-related education. Less than a third $(30 \%)$ had either business education or relevant financial management training of some sort.

On the nature of small and micro businesses in Ghana, the study concludes that upon a relatively flexible registration procedure and requirement, the owners normally doubles as the business manager (financial manager) and undertakes the day-to-day management of cash. This function includes identifying financial sources, financial acquisition and handling (utilization) of cash in the manner of safe-keeping, depositing at the bank and general control over funds. Others include decisions regarding investment of idle cash and necessary planning to maintain relevant cash (liquidity) levels for the business operations at all times.

Overall, the food, beverage and tobacco industry dominated $(15.3 \%)$, followed by the education sector $(12.4 \%)$. However, within the small business segment, the education sector dominated $(20 \%)$, followed by that of hospitality (12\%). The micro businesses had the food, beverage and tobacco sector as dominant (19\%), followed by the building, welding, metal and construction sector (13\%). On the meaning of financial management, only $13 \%$ of the respondents actually understood it. Regardless of the business segment, majority $(36 \%)$ of the respondents had misconceived that maintaining proper financial records was all about financial management. Really worrying is the fact that $13 \%$ of overall respondents stated that they did not understand the meaning of financial management.

Contrary to the reviewed theory and the conceptual framework (see Brealey\& Myers, 2003; McMenamin, 1999; and Van Horn \& Wachowicz, Jr. 2008), the study found that the respondents had mainly practiced cash book and other book-keeping functions in lieu of proper financial management practices. This situation, the study observed, raises some questions about the validity of the $13 \%$ respondents, who had indicated that they understood the meaning of financial management. Equally worrying is the fact that $12 \%$ of respondents indicated that they rather used their 'personal experience and/or strategy' of some sort in lieu of the concept.

Again, majority of the small enterprise owners had made decisions based on financial management (implications) thoughts and processes. In contrast, majority of the micro enterprise owners had adopted conventional practices which seemed haphazard, appears dangerous to their survival and possible growth into, at least, the small business segment (see also Nthejane, 1997). In addition, with their financial management skills the SMEOs utilized the financial management process by carefully evaluating each of the available sources of finance but prior to this endeavour, SMEOs had to identify these sources of finance. Majority (42\%) of the respondents (regardless of business segment) had found their financial sources through follow-ups on media reports and adverts. Precisely, majority (36\%) of the small enterprise owners had relied upon their personal connections and contacts. Many (52\%) of the micro enterprise owners had followed-up on media reports and adverts to list the funding sources available to their businesses. Still on the existing financial management processes, it is concluded that respondents selected their relevant funding sources with the first three leading considerations as: the use of any available source of capital; capacity to repay bearing in mind the uncertainties with operational volume (business trends); and the possible effects on cash or liquidity levels. Precisely, however, the small business respondents used proper financial management (scientific) indicators to select their sources of finance whilst the micro business respondents had significantly adopted conventional methods, which practices, could pose serious implications and threats to their business survival and consequently, their going-concern dreams.

Regarding the crucial process or function of allocating profits/returns generated from the enterprise's operations, $9 \%$ of respondents ploughed back their profits for business expansion. Disbursing as and when necessary was done by $7 \%$ of respondents overall. Quite specifically, majority (35\%) of the micro business owners invested their operational returns in excess of both fixed and working (ploughed back) capital in either co-operative credit unions (susu) or treasury bills/fixed deposits, with loans repayments rather carried out by $14 \%$ of their lot. Similarly, $14 \%$ of the small business owners rather invested their similar returns in treasury bills/fixed deposits with $15 \%$ of their proportion rather servicing their debts. Again, it is concluded that these investment practices, aimed at increasing profit and consequently enhancing the enterprise value, are in line with the theoretical framework (Brealey \& Myers, 2003).

We conclude that the Government of Ghana, on its part has put in place funding some interventions and established some departments and agencies in addition to licenses issued to several of NGOs to operate in this sector of the Ghanaian economy, with the objective, among others, of building or enhancing the necessary business (financial) management capacities. However, it appears these interventions and agencies are either inadequate or not making the necessary impact for now. Again, even though external financial management challenges like: unreliably poor general economic conditions; unreliable training promises by certain 
agencies and NGOs; business-unfriendly loans' terms and conditions; and relatively high cost of borrowing were assigned; internally however, majority (24\%) of respondents lacked the basic working knowledge in financial management and this crucial challenge was cited to have multiplier effects on both the number and types of other (associated) challenges.

Regardless of a business size, industry participation or business segment, a business owner-manager is expected to have acquired a reasonable level of education or training of some sort in order to adapt proactively to the financial management issues. To achieve this objective it is recommended that stakeholders of these business segments collaborate in tackling the crucial challenge of basic working knowledge in financial management among majority of the owner-managers. Specifically, resource persons from the business schools of both the polytechnics and the universities could be assisted to develop and regularly present business management skills training, including specific financial management capacity-building programmes at designated centres at the district capitals (to start with). This must be institutionalized to offer more permanent routine services. The existing agencies, departments and NGOs must be up and doing or a review of their set-up and operations carried out. Currently, it appears they may be more assertive and perhaps useful, if they were audited or monitored regularly in terms of their services to these businesses with documentary proofs.

Funds acquired must be based on grounded financial and operational strategic outlooks so that adding to their proper utilization, they would always inure to the benefit of the businesses and enhance the mutual benefits of the two parties (businesses and their financiers alike). Precisely, businesses are run proactively and such, financial planning in the form of forecasts, budgets, cost-benefit analysis, make or buy decisions, investment appraisal, sensitivity analysis, market research and trends, competitors' and stakeholder analysis must commonly be useful skills to apply. This way, cash and other financial resources generated by the respective enterprise's operations as well as other scarce resources would be prudently utilized to contribute to their profitability and expansion. However, these are the very skills in dire needs of the SMEOs themselves and they are expected to reach out for them. They must take the necessary steps, either by forming unions, through which vehicle they would have a stronger voice and attention or individually seek specific training through workshops, short-courses and so on. Fact is that without the necessary financial management knowledge, skills and practices, a lucrative business opportunity may be a mirage.

Future research is expected to concentrate on financial management on business segment specifics, for instance, only small enterprise owners' practices with gender specifics. It may also be useful to examine the specific focus and operations of the designated agencies and NGOs in order to fashion out the real challenge to be tackled. Finally, the impact of financial management practices on the businesses may be worth studying for appropriate documentation.

\section{References}

[1] Addai, P.K. (1994). The Impact of Business Advisory Centre on the Small-Scale Enterprises in Cape Coast Municipality, Unpublished B-Com Long Essay, Department of Economics and Business Studies, UCC, Cape Coast, Ghana.

[2] AGI (2006). Strengthening Industrial and Business Association in the Volta Region, The Friedrich Nuamann Foundation.

[3] Attom, B.E. (2013). Cash management Practices by Micro and Small-Scale enterprises at Kasoa in the Central Region of Ghana, Asian Journal of Business and Management Sciences, Vol.3, No.2, pp.1-12.

[4] Attom, B.E. and J.K. Mbroh (2012). Financial Management Made Easy: A Self-Tuition Approach, Accra: Adwinsa Publications (Gh.) Limited, p.1.

[5] Baker, H.K. (1991). Financial Management, New York: Harcourt Bruce Jovanovich.

[6] Boachie-Mensah, F.O. and E. Marfo-Yiadom (2005). Entrepreneurship and Small Business Management, Accra:Ghana Universities Press.

[7] Bolton Report (1991). Report of the Committee of Inquiry on Small Firms, HMSO, Cmnd 4811, London: HMSO.

[8] Bosa, G. (1969). The Financing of Small Enterprises in Uganda, Oxford University Press, Nairobi, Kenya.

[9] Brealey, R.A. and S.C. Myers (2003). Principles of Corporate Finance, $7^{\text {th }}$ ed., New York:McGraw-Hill/Irwin, p.3.

[10] Carpenter, M., Bauer, T. and B. Erdogan (2010). Introduction to Principles of Management, Jupiterimages Corporations, p.10.

[11] Daft, L.R. (2012). New Era of Management, $10^{\text {th }}$ ed., USA: South Western Congage Learning.

[12] Eyiah, A. (2001). An Integrated Approach to Financing Small Contractors in Developing Countries: A Conceptual Model, Construction Management Journal, Vol.19, pp.511-518.

[13] Ghana Statistical Services (2002). Poverty Trends in the 1990s, Accra: GSS.

[14] Keasey, K. and R. Watson (1994). The Bank Financing of Small Firms in the UK: Issues and Evidence, Small Business Economics, Vol.6, pp.349-362.

[15] Kufour, A.A. (2008). Employment Generation and Small Medium Enterprise Development in the Garment and Textile Manufacturing Industry in Ghana, Paper Presented at International forum on Sustainable Private Sector Development, Halifax, Nova Scotia, Canada.

[16] Levy, B. (1993). Obstacles to Develop Small and MediumSized Enterprises: An Empirical Assessment, World Bank Economic Review, Vol.7, No.1, pp.65-83.

[17] Logli, P. (1981). New Support for Small and Medium-Sized Enterprises in Developing Countries, The Courier, No.65, pp.96-98. 
[18] Maness, T.S. (1988). Introduction to Corporate Finance, New York: McGraw-Hill Book Company.

[19] Marfo-Yiadom, E. (2002). A Survey of Cash Management Practices of Selected firms In Accra-Tema Metropolitan Area of Ghana, The Oguaa Journal of Social Science, Vol.3, No.1, pp.165-182.

[20] Marfo-Yiadom, E. (2009). Essentials of Financial Management, Accra:Woeli Publishing Services.

[21] Mbroh, J.K.(2011). Methods of Accounting Practices by Small Business Owners in the Cape Coast Metropolitan Area of Ghana, Journal of Polytechnics in Ghana, Vol.5, No.1, pp.129-151.

[22] Mbroh, J.K. (2012a). An Investigation of Small and MicroEnterprise Owners' Perception Towards Financial Credit Offered by Commercial Banks in the Cape Coast Metropolitan Area, Asian Economic and Financial Review, Vol.2 No.1, (March), pp.171-180.

[23] Mbroh, J.K. (2012b). Cash Management Practices of Small Business Owners in the Cape Coast Metropolitan Area of Ghana, Asian Economic and Financial Review, Vol. 2, No.1, pp. 40-58.

[24] Mbroh, J.K. and B. Assah (2015). Financial Records Keeping and Business Decision-Making Practices by Small and Micro Enterprise Owners in Ghana - Evidence from the Central Region, International Journal of Economics, Commerce and Management, United kingdom, Vol.3, Issue 8, (August), pp.467-491.

[25] Mbroh, J.K. and K.A. Koomson (2015), The Credit Policies and Credit Finance Creation Practices by Commercial Banks in Ghana: Perspectives of Staff and Clients of the Prudential Bank Limited, International Journal of Economics, Finance and Management Sciences, USA, Vol.3, No.5, pp.441-452.

[26] Mbroh, J.K. and S. Quartey (2015). The Funding Cycle of Small and Micro Enterprises In Ghana - Evidence of StageBy-Stage Sources and Challenges from The Central Region, International Journal of Economics, Commerce and Management, United kingdom, Vol.3, Issue 8, (August), pp.290-314.
[27] McMenamin, J. (1999). Financial Management: An Introduction, London: Routledge, pp.617-627.

[28] National Board for Small Scale Industries (2000). Small-Scale Businesses in Ghana, Accra: NBSSI.

[29] NLC Decree 252 (1968). Co-operative Decree, NLC Decrees, Ghana.

[30] Nthejane, P. (1997). The Process of Policy Formulation in Lesotho, In Franz, J. Oesterdiekoff, P. (eds). SME Policies and Policy Formulation in SADC Countries, Botswana: Friedrich Ebert Stiftung.

[31] Oshagbemi, T.A. (1985). Small Business Clinic, Training Committee Report on Small Business Management in Nigeria.

[32] Pinches, G.E. (1990). Essentials of Financial Management, New York: Harper and Row.

[33] Quartey, P. and D. Kayanula (2000). The Policy Environment for Promoting Small and Medium Enterprises in Ghana and Malawi, IDPM (University of Manchester) Finance and Development Working Paper, No.15.

[34] Ross, S.A., Westerfield, R.W. and B.D. Jordan (2004). Essentials of Corporate Finance, $4^{\text {th }}$ ed., New York: McGraw Hill/Irwin, p.5.

[35] UNCTAD (2000). Accounting by Small and Medium-Size Enterprises, Reproduction:The Professional Accountant, Ghana, (March-April, 2002), pp.11-35.

[36] UNIDO (1999). Supporting Private Industry, Capacity Building for Private Sector Development in Africa, PSD Technical Working Papers Series, Working Paper, No.3.

[37] Van Horn, J.C. and J.M. Wachowicz, Jr. (2008). Fundamentals of Financial Management, $13^{\text {th }}$ ed., England: FT Prentice Hall, p.2.

[38] Wynarczyck, P., Watson, R., Storey, D., Short, H. and K. Keasey (1993). The Managerial Labour Market in Small and Medium-Sized Firms, London: Routledge. 